\title{
Diagnostic of pulmonary abscesses in foals - Comparison of sonographic and radiographic examination
}

\author{
Monica Vennerl, Saskia M. Walther², Beate Münzer ${ }^{3}$ and Peter Stadler ${ }^{4}$ \\ 1 Tierärztliche Klinik für Pferde, Destedt, Germany \\ 2 Praxis für Pferde am Dobrock, Oberndorf, Germany \\ ${ }^{3}$ Freie Universität Berlin, Klinik für Pferde, Germany \\ ${ }^{4}$ Stiffung Tierärztliche Hochschule Hannover, Klinik für Pferde, Hanover, Germany
}

\begin{abstract}
Summary: The aim of this study was to evaluate the diagnostic value of sonographic and radiographic examination in an early state of abscess-forming pneumonia in foals. Clinical and haematological examination as well as thoracic sonography and radiography was performed on 61 foals on a Warmblood stud. 19 foals were healthy and showed no clinical, no haematological and no sonographic signs of pneumonia. 42 foals were clinically suspicious of pneumonia or showed a leukocytosis and had at least one pulmonary abscess at sonography. Altogether 90 abscesses were detected sonographically in the 42 sick foals. Two chest radiographs (X-ray beam right to left and left to right) were taken of each foal and evaluated by three experienced equine internists blinded to the clinical findings of the foals. The number and location of abscesses were documented. A discrepancy was noted in the findings of the radiographs for signs of abscesses between the observers. Radiographic evaluation revealed an abscessing pneumonia in only 20 of the 42 sick foals. The location of the abscesses revealed at sonography and radiology agreed in only 21 abscesses. Finally a good match between radiologic and sonographic findings of abscesses was assessed in the area restricted to the central region of the lung. The results indicate that thoracic radiography is less reliable under field conditions compared to sonography. Sonography seemed to be more sensitive for the diagnosis of pulmonary abscesses in foals.
\end{abstract}

Keywords: foal / pneumonia / pulmonary abscesses / radiography / ultrasonography /diagnostic imaging

Citation: Venner M., Walther S. M., Münzer B., Stadler P. (2014) Diagnostic of pulmonary abscesses in foals: Comparison of sonographic and radiographic examination. Pferdeheilkunde 30, 561-566

Correspondence: Dr. Dr. habil. Monica Venner PhD, Pferdeklinik Destedt, Trift 4, 38162 Destedt, Germany, E-mail: mvenner@gmx.de

\section{Introduction}

Abscessing pneumonia due to Strep. equi zoopepidemicus or more often due to Rhodococcus equi (R. equi) causes economical losses worldwide in the horse breeding industry (Giguere et al. 2011, Lavoie et al. 1996). Foals at the age of 1 to 6 months can be affected by this disease. In studs with endemic R. equi-pneumonia disease rate ranges from 5 to $80 \%$, which implicates high veterinary and treatments costs leading to a high economical pressure for some breeders. A diagnosis in an early stage of the disease is required to initiate an appropriate treatment in order to avoid the loss of foals (Cohen et al. 2000, Giguère 2001, Cauchard et al. 2013).

Especially under field conditions making an early diagnosis is difficult for the practitioner (Falcon et al. 1985, Althaus 2004). The clinical evaluation associated with the haematological examination is a reliable tool for detection of suspicious foals but not for diagnosis, as many foals do not show any clinical findings despite large pulmonary abscesses (Zink et al. 1986). As identification of $R$. equi at microbiological examination of airway samples has a sensitivity as low as $50 \%$, alternatives for the diagnosis of R. equi pneumonia are needed (Venner et al. 2007). Imaging techniques as sonography and radiography are recommended to detect abscesses in the lung of foals, with up to now a higher diagnostic value attributed to radiography (Ramirez et al. 2004). Though radiography seems to be more popular in the view of practitioners, a disadvantage of this diagnostic technique is besides the exposure to radiation, the size and the mobility of the patient that might lower the quality of radiographs necessary to evaluate findings of a small size and the quality of chest radiographs taken under field conditions (Farrow 1981). On the other hand thoracic sonography is very easy to perform under field conditions using portable devices. The clear limitation of this method is that it can only detect lesions in the peripheral areas of the lung (Reef 1990, 1991).

The aim of the study was to reevaluate the diagnostic value of sonography and radiography in foals with abscess-forming pneumonia under field conditions.

\section{Material and Methods}

On a German warmblood stud 61 foals between 8 and 148 days of age were divided into two groups. Group one included healthy foals and group two included foals that were suspicious of having abscess-forming pneumonia. Foals were considered to be healthy, if they showed no clinical signs of respiratory disorder, had a total white blood cell count less than $13.000 / \mu \mathrm{l}$ and had no abscesses at thoracic sonography. Foals were considered to be sick if they showed respiratory symptoms and/or had a white blood cell count above $13.000 / \mu \mathrm{l}$. All of these foals had at least one abscess at sonography.

To localise precisely the findings on thoracic radiographs and at sonography of the lung and to compare the findings with both imaging techniques, the rib cage was divided into a coordinate system. The intercostal spaces were counted from cranial to caudal. Furthermore each intercostal space was divided from dorsal to ventral into three sections: $A, B$ and $C$. 
The sonographical examination was performed with a portable ultrasound machine with rechargeable battery (Sonovet 2000, Kretztechnik AG, Tiefenbach, Austria) with a $7.5 \mathrm{MHz}$ linear transrectal transducer (LV5-9AD Sono Ace, Oseosys Co, Seoul, Korea).

All foals were clipped in the area of the lung and the skin was degreased with alcohol solution $99 \%$ and coupling gel was applied. The thorax was accurately scanned from the fourth to the 12th intercostal space from dorsal to ventral. An abscess was defined as an hypoechoic region surrounded by an hyperechoic margin, indicative of adjacent aerated lung tissue (Fig. 1). Localization and diameter of the abscess were documented on a form.

The radiographic examination was performed with a portable anode tube (HF 90/20, Gierth, Riesa, Germany). The foals were radiographed in a standing lateral position. Two chest radiographs, one from each side of the thorax, were taken. In each foal the right 10 th. rib and the left 11 . rib were marked with a radio opaque bar. These markers enabled the observers to localise precisely the abscesses and to compare the results to those of the sonography. All radiographs were evaluated by a veterinary radiologist and two experienced equine internists, independently from each other. The observers were blinded to clinical and sonographical findings. An abscess was considered to be diagnosed, if it was found at the same localisation from at least two of the three observers. A pulmonary abscess was defined as a variable-sized nodule or mass, homogenous or with a cavity (Fig. 2). On the basis of the

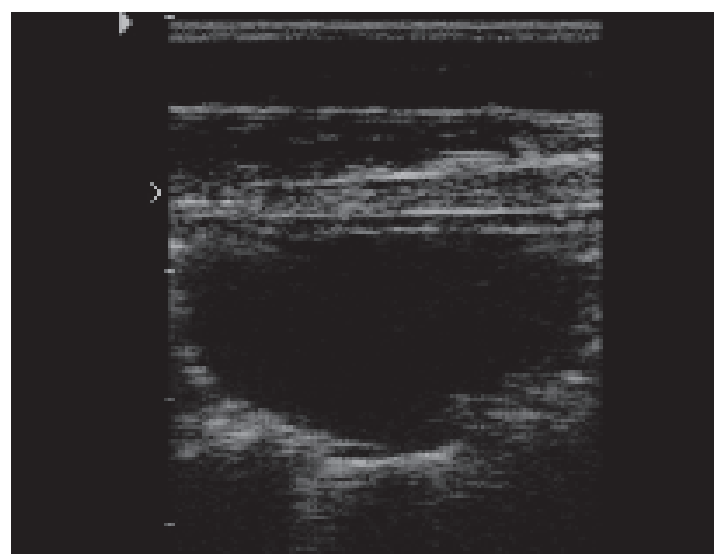

Fig 1 Sonographic image of a pulmonary abscess (linear transducer placed in the right 6th intercostal space (97-day-old foal with an abscess-forming pneumonia)

Sonographisches Bild eines Lungenabszesses (linearer Schallkopf im rechten 6.ten Interkostalraum eines 97 Tage altes Fohlen) coordinate system the diagnostic findings of both imaging techniques were compared.

\section{Results}

In the group of healthy foals no abscesses were diagnosed at radiography. Consequently the following comparison is restricted to foals with pulmonary abscesses. All 42 foals were between 37 and 148 days of age.

\section{Sonography}

In 42 foals a total number of 90 abscesses were diagnosed, 45 on each side of the thorax. Each of these foals had at least one abscess. The highest number of abscesses that was diagnosed in one of the foals was 9. Abscesses were found in all examined inter costal spaces (Fig. 3). 12 abscesses were observed in the dorsal, 53 in the middle and 25 in the ventral lung region.

\section{Radiography}

Observer I diagnosed a total number of 41 focal densifications in 17 of the foals. Observer II diagnosed 64 focal den-

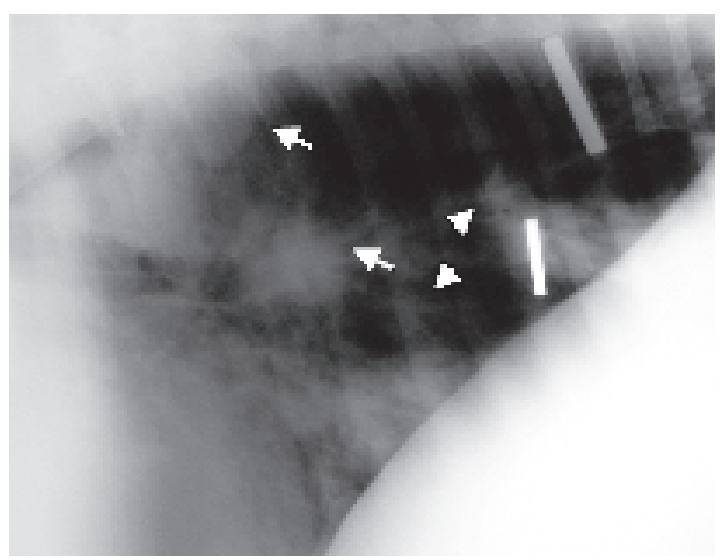

Fig. 2 Radiograph from a 86 days old foal with four abscesses (see arrows). The radiograph was taken in a lateral standing position with the X-ray cassette on the left side of the thorax. The two radio opaque bars marked the 10 th. rib on the right side, the 11 th. rib on the left side of the thorax.

Analoge latero-laterale Röntgenaufnahme eines 3 Monate alten Fohlens mit vier fokalen Verdichtungen (Lungenabszessen). Die röntgendichten Marker sind auf der 10. rechten und auf der 11. linken Rippe fixiert.

Tab. 1 Findings on both left and right chest radiographs of 42 foals with pulmonary abscesses. / Übereinstimmungen zwischen den Befunden der rechten und linken Thoraxaufnahmen

\begin{tabular}{|c|c|c|c|}
\hline & & Number of pulmonary absecesses & Number of matching findings on both radiographs \\
\hline \multirow[t]{2}{*}{ Observer 1} & right & 16 & \multirow[t]{2}{*}{$(14 / 41)(34 \%)$} \\
\hline & left & 25 & \\
\hline \multirow{2}{*}{ Observer 2} & right & 25 & \multirow{2}{*}{$(15 / 52)(29 \%)$} \\
\hline & left & 27 & \\
\hline \multirow[t]{2}{*}{ Observer 3} & right & 36 & \multirow{2}{*}{$(22 / 80)(27,5 \%)$} \\
\hline & left & 44 & \\
\hline
\end{tabular}

le: radiographic cassette on the left side; ri: radographic cassette on the right side 
sifications in 25 foals. Observer III diagnosed 114 focal densifications in 32 foals. The diagnosis of at least two observers matched in 20 foals with 27 focal densifications. Pulmonary focal densifications were detected from the 6th to the 11 th intercostal space and 5 were observed in the dorsal, 13 in the middle and 9 in the ventral lung region (Fig. 4).

Conformity of radiographic findings on both left and right radiographs was poor and found only in 27 to $34 \%$ of the abscesses depending on the observer (Table 1).

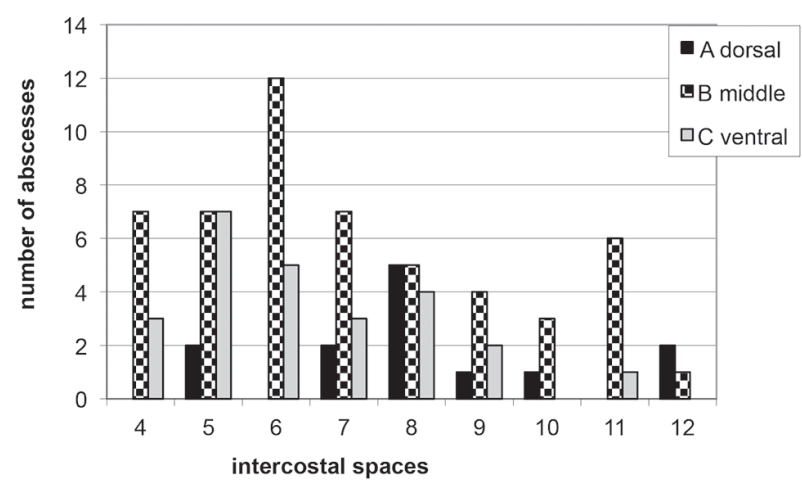

Fig. 3 Distribution of pulmonary abscesses diagnosed by sonography ( $\mathrm{n}=42$ foals with 90 abscesses).

Lokalisation der 90 Lungenabszesse, die bei den 42 erkrankten Fohlen sonographisch diagnostiziert wurden.

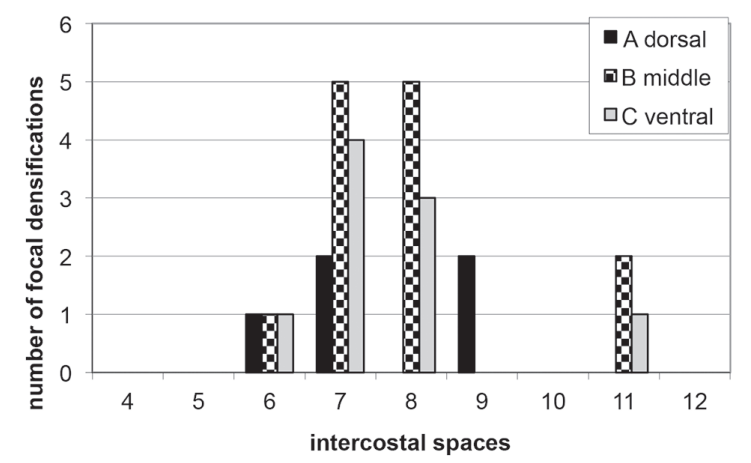

Fig. 4 Distribution of pulmonary focal densifications diagnosed by radiography ( $\mathrm{n}=20$ foals with 27 abcsesses).

Lokalisation der Röntgenverdichtungen bei 20 Fohlen

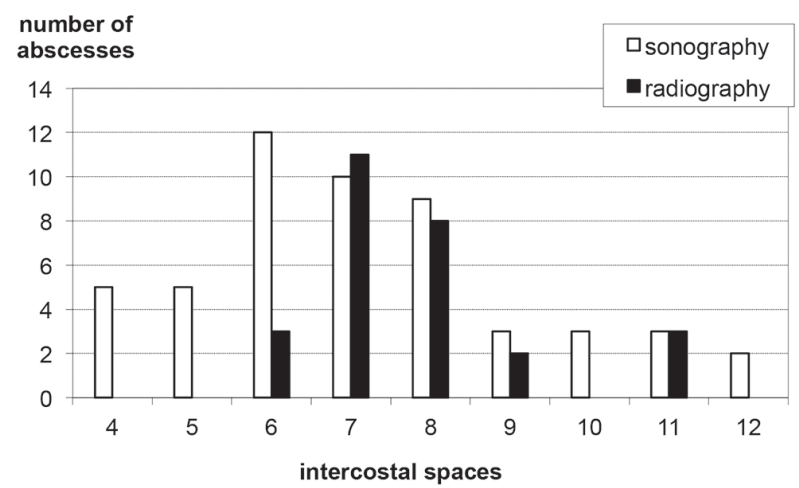

Fig. 5 Distribution of pulmonary abscesses diagnosed by radiography and by sonography ( $\mathrm{n}=20$ foals).

Lokalisation der röntgenologischen und der sonographischen Befunde $(n=20$ Fohlen)
Comparison between sonographical and radiographical results:

The radiological examination revealed 27 focal densifications detected by at least two of the observers in a total number of 20 foals. In these 20 foals 52 abscesses were diagnosed at sonography. In only 17 of these foals the localisation of 21 findings $(52 \%)$ was consistent in both diagnostic imaging techniques (Fig. 5). The highest consistency of sonographical and radiographical finding was detected in the 6th to 10th intercostal spaces. On the contrary only few abscesses were diagnosed in the cranial and the caudal areas of the chest radiographs.

\section{Discussion}

As stated in previous studies both imaging techniques, sonography and radiography, are good diagnostic methods to evaluate an abscess-forming pneumonia in foals (Falcon et al. 1985, Althaus 2004). Furthermore radiography was shown to have a valuable prognostic value in severe cases of R. equi pneumonia in foals (Giguère et al. 2012). But only one study has compared both methods in foals with pulmonary abscesses in the earlier course of the disease (Ramirez et al. 2004).

In contrast to the results of Ramirez et al. (2004), indicating that less pulmonary abscesses (in 12 out of 14 foals) were detected at sonography than on the chest radiographs, in the present study, more foals with pulmonary abscesses were detected at sonography than at radiography. None of the observers was able to diagnose as many sick foals by radiographic evaluation as the sonographic evaluation did. Even in cranial- and caudo-ventral regions of the lung abscesses are still well visualized by ultrasound imaging (Reef 1990, 1991, Reimer 1990). In the cranioventral areas of the lungs (4th to 6th intercostal space) 22 abscesses were detected by ultrasound and only 3 by radiography (Fig. 3). In this particular area of the thorax the cardiac silhovette covers a large part of the lung parenchyma of the ventral region of right and left lobus caudalis and does not allow precise evaluation on lateral thoracic radiographs. A similar situation is found in the caudal peripheral areas of the lung that superimpose to the diaphragm (Rantanen 1986).

Furthermore the assignment of an abscess to one side of the thorax, which can be useful in evaluating the response to therapy, is immediate at sonography. At radiography in standing lateral position most parts of the lungs are visible but right and left lungs overlay each other (Bolz 1936). Consequently an assignment to one side is only possible in some cases comparing the size of abscesses on each radiograph (Renando et al. 1979, Zink et al. 1986). In the present study only $27.5 \%$ to $34 \%$ of the abscesses were concordant to one side considering the findings of the three observers. As two radiographs were taken, one from each side, the interpretation of the radiographs revealed different numbers of abscesses on each $x$-ray of each foal. Therefore one single radiograph seems to be suggestive but not sufficiently sensitive.

The evaluation of thoracic radiographs of horses including physiological findings has always been a challenge for both 
the radiologist and the veterinarian (Sande et al. 2004). The present results show that the interpretation of chest radiographs can differ highly between observers. In analogy to rules in human radiology, accuracy of evaluation depends on quality of chest radiographs, on knowledge and experience of the observer as well as the technique of examination and the moment in the course of disease (Bolig 1976). Furthermore the size of the finding and the duration of viewing are also important for the interpretation of chest radiographs (Oestmann et al. 1988).

In the present study 90 pulmonary abscesses were diagnosed in 42 foals by sonography whereas only 27 abscesses were found in 20 foals on chest radiographs. These results suggest that radiography is less sensitive than the sonography to detect early focal pulmonary disorders. However, abscesses without connection to the pleura cannot be detected by sonographical examination (Reef 1990, Reimer 1990). Therefore in a case of clinical suspicion of R. equi pneumonia, sonography could be performed first and if no abscesses are found, two chest radiographs ought to be done to obtain the highest security in the examination of a foal.

\section{References}

Althaus O. P. (2004) Sonographie: Eine Hilfe zur Früherkennung von Rhodococcus equi-Pneumonie beim Fohlen. Diss. Med. Vet. Hannover

Bolig H. (1976) Die röntgenologischen Differentialdiagnosen von Lungenerkrankungen. Internist. Praxis 16, 267-276

Bolz W. (1936) Die röntgenologische Differenzierung des Lungenbildes beim Pferd. Deutsche Tierärztl. Wschr. 22, 394-398

Cauchard S., Giguère S., Venner M., Muscatello G,. Cauchard J., Cohen N. D., Haas A., Hines S. A., Hondalus M. K., Horohov D. W., Meijer W. G., Prescott J. F., Vázquez-Boland J. (2013) Rhodococcus equi research 2008-2012: Report of the 5th Intern. Havemeyer Workshop. Equine Vet. J. 45, 523-526

Cohen N. D., Chaffin M. K., Martens R. J. (2000) Control and prevention of Rhodococcus equi pneumonia in foals. Comp. Cont. Educ. Pract. Vet. 22, 1062-1070

Falcon J., Smith B. P., O Brien T. R., Carlson G. P., Biberstein E. (1985) Clinical and radiological findings in Corynebacterium equi pneumonia of foals. J. Am. Vet. Med. Assoc. 186, 593-599

Farrow C. S. (1981) Equine Thoracic Radiology. J. Am. Vet. Med. Assoc. 179, 611-615

Giguère S. (2001) Rhodococcus equi Pneumonia. Proceedings Ann. Congress Am. Ass. Equine Pract. 47, 456-467

Giguère S., Cohen N., Chaffin K., Slovis N., Hondalus M. K., Hines S., Prescott J. F. (2011) Diagnosis, Treatment, Control, and Prevention of Infections Caused by Rhodococcus equi in Foals. J. Vet. Intern. Med. 25, 1209-1220

Giguère S., Roberts G. D. (2012) Association between radiographic pattern and outcome in foals with pneumonia caused by Rhodococcus equi. Vet. Radiol. Ultrasound 53, 601-604

Giguère S. (2001) Rhodococcus equi Pneumonia. Proceedings Ann. Congress Am. Ass. Equine Pract. 47, 456-467

Lavoie J. P., Fiset L., Laverty S. (1994) Review of 40 cases of lung abscesses in foals and adult horses. Equine Vet .J. 26, 348-352

Lester G. D., Lester N. V. (2001) Abdominal and thoracic radiography in the neonate. Vet. Clin. Equine Pract. 17, 19-46

Oestmann J. W., Greene R., Kushner D. C., Bourgouin P. M., Linetzky L., Leewellyn H. J. (1988) Radiology 166, 451-453

Ramirez S., Lester G. D., Roberts G. R. (2004) Diagnostic contribution of the thoracic ultrasonography in 17 foals with Rhodococcus equi pneumonia.Vet. Radiol. Ultrasound 45, 2-5

Rantanen N. W. (1986) Diseases of the thorax. Vet. Clin. North Am. Equine Prac. 2, 49-66
Reef V. B. (1990) Outcome and return to performance in horses with pleuropneumonia evaluated ultrasonographically. Proceedings of the 8th Ann. Am. College of Vet. Intern. Med. Forum 573-575

Reef V. B. (1991) The use of diagnostic ultrasound in the horse. Ultrasound Quart. 9, 1-33

Reimer J. M. (1990) Diagnostic ultrasonography of the equine thorax. Comp. Contin. Educ. Pract. Vet. 12, 1321-1327

Renando V. T., Quick C. B. (1979) Radiographic Interpretation equine radiology- the thorax. Mod. Vet. Pract. 4, 51-54

Sande R. D., Tucker R. L. (2004) Radiology of the equine lungs and thorax. Equine Respiratory Diseases, P. Lekeux (ed); International Veterinary Information Service, Ithaca, USA

Venner M., Heyers P., Strutzberg-Minder K., Lorenz N., Verspohl J., Klug E. (2007) Detection of Rhodococcus equi by microbiological culture and by polymerase chain reaction in samples of tracheobronchial secretions of foals. Berl. Münch. Tierärztl. Wschr. 120,126-33

Zink M. C., Yager J. A., Smart N. L. (1986) Corynebacterium equi infections in horses, 1958-1984: A review of 131 cases. Can. J. Vet. Res. 27, 213-217

Erweiterte Zusammenfassung

Ziel der vorgelegten Studie war es, den diagnostischen Wert der sonographischen und röntgenologischen Lungenuntersuchung bei der abszedierenden Pneumonie des Fohlens zu ermitteln. Dabei sollte insbesondere überprüft werden, ob unter Praxisbedingungen Lungenabszesse in einem frühen Stadium der Erkrankung mit einem oder mit beiden bildgebenden Verfahren erkannt werden können. Darüberhinaus wurde die Befundung der Röntgenaufnahmen der Lunge von gesunden und kranken Fohlen durch drei erfahrenen Röntgenbetrachter verglichen werden.

Die Untersuchung wurde an 61 Fohlen auf einem Gestüt in Norddeutschland durchgeführt. Nach der Allgemeinuntersuchung, der klinischen Lungenuntersuchung und nach Bestimmung der Blutleukozytenkonzentration, wurden sonographische und radiologische Untersuchungsergebnisse der Lunge von lungenkranken Fohlen ( $n=42)$ mit denen von lungengesunden $(n=19)$ verglichen. Bei der sonographischen Untersuchung wurden die Anzahl und die Lokalisation der Lungenabszesse (Fig. 1) auf jeder Thoraxseite ausgewertet. Die Lokalisationen der Lungenabszesse wurden mit Hilfe eines Koordinatensystems über dem Lungenfeld unter Orientierung an den Interkostalräumen ermittelt. Dazu wurden die Interkostalräume vom 4. bis zum 12 Rippenzwischenraums von dorsal nach ventral in drei Regionen unterteilt (dorsal, Mitte, ventral) und sonographisch untersucht. Ausserdem wurden von jedem Fohlen ein latero-laterales Röntgenbild von rechts und eins von links erzielt, mit Markierung von 2 Rippen, so dass auch hier die fokalen Verdichtungen präzise lokalisiert werden konnten (Fig. 2). Die Röntgenbilder wurden von drei Betrachtern, unabhängig voneinander und ohne Angabe des 
klinischen Vorberichtes, ausgewertet. Dabei wurden, wie bei der sonographischen Untersuchung, die Anzahl und die Lokalisation der Abszesse beurteilt. Röntgenologisch wurde ein Lungenabszess als gesicherte Diagnose angenommen, wenn dieser von mindestens zwei der drei Betrachter an derselben Lokalisation angegeben wurde. Die röntgenologischen Befunde der beiden Thoraxseiten wurden verglichen. Zuletz† wurden die Röntgenbefunde anhand der Koordinatenpunkte mit den sonographischen Befunden verglichen.

Bei den 42 Fohlen mit Verdacht auf Lungenerkrankung insgesamt 90 Lungenabszesse sonographisch diagnostiziert (Fig. 3). Lokalisierte schalleitende Befunde waren in jedem Interkostalraum und in jeder Ebene (ventrale, mittlere und dorsale Zone) zu ermitteln. Bei den 19 gesunden Fohlen wurden keine röntgenologischen Hinweise auf eine fokale Verdichtung des Lungengewebes diagnostiziert. Bei den 20 Probanden, bei denen ein übereinstimmendes Ergebnis bei der Beurteilung der Röntgenbilder ermittelt wurde, wurden sonographisch 52 und röntgenologisch nur 27 Lungenabszesse diagnostiziert (Fig. 5). Bei insgesamt 21 Abszessen wurde eine Übereinstimmung der Lokalisation bei den beiden Untersuchungsmethoden festgestellt. Die Übereinstimmungen zwischen den röntgenologischen und sonographischen Befunden war bei Abszessen, die sich im Zentrum der Lunge (7. und 8. Interkostalraum) befanden, gut. Eine schlechte Übereinstimmung wurde für die kranialen (4. bis 6. Interkostalraum) und kaudalen (10.-12. Interkostalraum) Areale der Lunge ermittelt.

Der Vergleich der Röntgenbefunde auf der rechten und der linken Thoraxaufnahme jedes Fohlens ergab für jeden Betrachter nur eine geringe Übereinstimmung $(27,5 \%$ bis
$34 \%)$. Somit wird nur jeder dritte Befund, der auf einer Thoraxaufnahme diagnostiziert wird, auch auf der Thoraxaufnahme des anderen Strahlgangs erkannt.

Die Untersuchung zeigte, dass im frühen Stadium der abszedierenden Lungenerkrankung des Fohlens die röntgenologische Untersuchung des Thorax zur Diagnostik von Lungenabszessen im Vergleich zur Sonographie unter Praxisbedingungen ein aufwendiges und weniger sensibles Verfahren ist. Ausserdem differiert die Befundung von fokalen Verdichtungen des Lungengewebes unter drei erfahrenen Betrachtern erheblich. Eine eindeutige Interpretation der Befunde gelang nur selten, somit war radiologisch oft keine eindeutige Diagnose möglich. Ausserdem ist es notwendig eine Röntgenaufnahme mit rechtem und eine mit linkem latero-lateralen Strahlengang zu erzielen, denn das Wiedererkennen eines Befundes auf beiden Aufnahmen gelingt nur in einem Drittel der Befunde. So wird die Diagnose deutlich verbessert, wenn je eine Aufnahme jeder Seite gemacht wird, was ungünstiger weise die Strahlenbelastung der Anwesenden erhöht.

Die wenig belastende sonographische Untersuchung stellte sich dagegen als weniger aufwendig und unter Praxisbedingungen mit gutem Ergebnis einsetzbar dar. Insbesondere sind mit dieser Untersuchungsmethode abszedierende Pneumonien beim Fohlen auch im frühen Stadium erfassbar. Die Grenze der Sonographie bei der Lungenuntersuchung besteht darin, dass nur pleuranahe Befunde erfasst werden und deshalb tiefliegende Lungenveränderungen übersehen werden. So empfiehlt sich, bei nicht eindeutigen sonographischen aber verdächtigen klinischen Befunden, die Röntgendiagnostik zusätzlich einzusetzen. 